\title{
THE EFL STUDENTS' NARRATIVE PARAGRAPH WRITING OF THE SECOND SEMESTER STUDENTS OF STATE INSTITUTE ISLAMIC STUDIES (IAIN) SAMARINDA: A SYNTACTIC ANALYSIS
}

\author{
La Ode Sanu \\ Akademi Bahasa Asing Colorado Samarinda \\ sanu.butonandeslan@gmail.com
}

\begin{abstract}
This study concerned on the EFL students' ability and analyzed the sentence patterns of syntax on the narrative paragraph writing. The QUANTQUAL of mixed methods design was used in this study. The quantitative data gathered from the test of narrative paragraph writing by involving 30 EFL students of IAIN Samarinda. The qualitative data gathered from the 10 selected documents of narrative paragraph writing that met the criteria. The findings showed that the EFL students' ability of narrative paragraph was categorized excellent (80.33). The highest ability was the writing aspect of organization $(86.65 \%)$ followed by vocabulary $(84.00 \%)$, content $(83.33 \%)$, mechanics $(78.60 \%)$, and language use $(69.08 \%)$. The sentence patterns of syntax found on the EFL students' narrative paragraph; its verbs were followed by direct object, infinitive, pronoun, present participle, adverbial phrase, that-clause, conjunctive-clause, gerund, direct objectpreposition-prepositional object, complement of distance and time, verb alone, predicative and preposition-prepositional object.
\end{abstract}

Keywords: Writing, Narrative Paragraph, Sentence Patterns of Syntax

\section{INTRODUCTION}

In Indonesia, the status of English is as a foreign language for Indonesian students that is learned in all levels of education (Rochman, 2003; Ivone, 2005; Nurhanifah \& Widayati, 2005; Lie, 2007; and Lauder, 2008). It means that English is consciously studied and used in a certain place and it is not used in daily communication in their environment. However, seeing the importance of English that is used for communication of human life in all aspects such as economic, culture, business, politic, administration, science and academia (Crystal, 2003), it could be ignored that English should be learned.

In the university context, writing is one of English skills that should be mastered by EFL students in order to be able to communicate in the written form since the general objective of writing course for students in university level is enable students to communicate in written English with different specific objectives and emphasis for each course level (Widiati, 2002). She added that for students of second semester who took the writing course aiming to develop their ability in writing English paragraphs. Indeed, the narrative paragraph

Script Journal Volume 1, Issue 1, April 2016 || ISSN 2477-1880 || E-ISSN 2502-6623 http://jurnal.fkip-uwgm.ac.id/index.php/Script 
was focused to be used in this study since it was one of the kinds of paragraphs studied by the EFL students.

Furthermore, the reasons why the researcher was interested in conducting this study were related to the importance of writing and syntax for the success and effectiveness of English learning. Firstly, in the EFL context, writing is important skill in teaching and learning since it is useful to motivate students' thinking, organizing ideas, developing their ability to summarize, analyze and criticize (Rao, 2007). He also added that writing strengthens students' learning, thinking, and reflecting on the English. Moreover, the aim of studying syntax is to illustrate the patterns of a language and to analyze its structure of sentences systematically. By having the knowledge of writing and syntax, the EFL students could be able to produce good English sentences syntactically; as a result, they could be able to communicate their ideas in the written form effectively and meaningfully. This study aimed to investigate the EFL students' ability in writing the narrative paragraph and to find out the sentence patterns of syntax found on the students' narrative paragraph.

\section{METHODOLOGY}

This study used the QUAN-QUAL of mixed methods design. It combined quantitative and qualitative approaches by including both quantitative and qualitative data in a single study (Gay, Mills, \& Airasian, 2012). In this study quantitative data dealt with the EFL students' narrative paragraph ability and qualitative data related with the sentence patterns of syntax made by the EFL students in writing the narrative paragraph. The researcher involved 30 EFL students of the second semester of State Institute Islamic Studies (IAIN) Samarinda in the academic year 2015/2016 by using simple random sampling. They were asked to write the narrative paragraph based on the free topic and the determined topics given. Then their writing result was evaluated to know their ability using the scoring system presented by Jacobs et al. (1981) consisted of content, organization, vocabulary, language use/grammar, and mechanics. Furthermore, the EFL students' document or the narrative paragraph writing test result was also used as the data source, where their sentences were analyzed of its syntax patterns using the verb patterns of syntax of Hornby (1976) where the patterns divided into 25 types. Here, the researcher selected the documents that meet the criteria. Moreover, the qualitative data were analyzed in which its procedures used the flow model data analysis of.

Script Journal Volume 1, Issue 1, April 2016 || ISSN 2477-1880 || E-ISSN 2502-6623 


\section{FINDING}

The findings of this study were the EFL students' ability in composing the narrative paragraph and the sentence patterns of syntax found on their narrative paragraph. The data presented below;

\section{The EFL Students' Ability of Narrative Paragraph}

To know the EFL students' ability, they were asked to write the narrative paragraph. Their writing result was evaluated based on the five criteria, namely content, organization, vocabulary, language use/grammar, and mechanics. Further, to get the trustworthiness the EFL students' score, the three scorers were involved. Then, the scores were merged to get the average score of each student.

From the calculation result, the total of the students' score was 24100.00 and the number of students was 30 students. So, the mean score of the students' ability of narrative paragraph writing was 80.33. Furthermore, the description of the students' narrative paragraph score could be seen the following table:

\begin{tabular}{clc}
\hline \multirow{2}{*}{ Interval } & \multirow{2}{*}{ Qualification } & The Number of the Students \\
\cline { 3 - 3 } & & Frequency \\
\hline $80-100$ & Excellent & 20 \\
$70-79$ & Good & 8 \\
$60-69$ & Fair & 1 \\
$0-59$ & Poor & 1 \\
\hline
\end{tabular}

Table 1 The Frequency of The Students' Narrative Paragraph Score

Based on the table above, the percentage of the EFL students' narrative paragraph writing ability could be seen below:

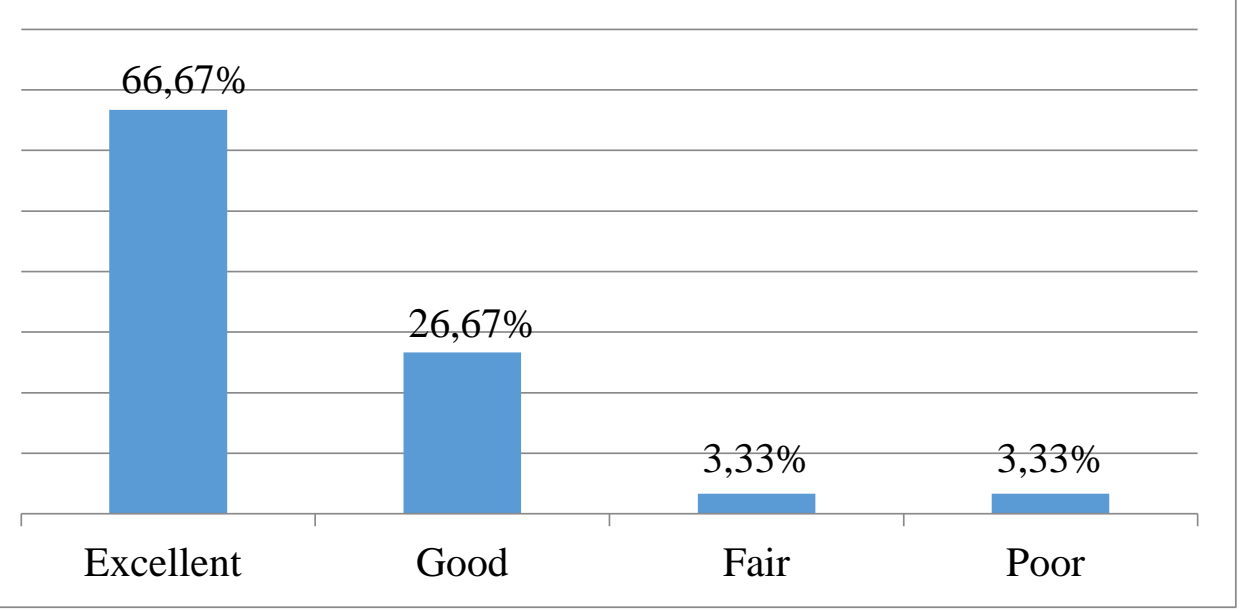

Figure 1 The Percentage of The Students' Narrative Paragraph Writing Ability 
Based on the table 1 and the figure 1, the EFL students' ability in writing the narrative paragraph showed that $20(66.67 \%)$ were excellent categorized, $8(26.67 \%)$ good categorized, $1(3.33 \%)$ was fair and poor categorized. In addition the mean score of the EFL students' ability based on each of writing aspects as follow:

\begin{tabular}{lccc}
\hline \multirow{2}{*}{ The Aspects of Writing } & \multicolumn{3}{c}{ The Score of the Students' Narrative Paragraph Writing } \\
\cline { 2 - 4 } & Total & Mean & \% The Students' Ability \\
\hline Content (30) & 750.00 & 25.00 & 83.33 \\
Organization (20) & 520.00 & 17.33 & 86.65 \\
Vocabulary (20) & 504.00 & 16.80 & 84.00 \\
Language Use (25) & 518.00 & 17.27 & 69.08 \\
Mechanics (5) & 118.00 & 3.93 & 78.60 \\
\hline
\end{tabular}

Table 2 The Students' Narrative Paragraph For Each Of Writing Aspects

Further clear description, the percentage of the EFL students' ability in writing the narrative paragraph for each of writing aspects could be seen the following diagram:

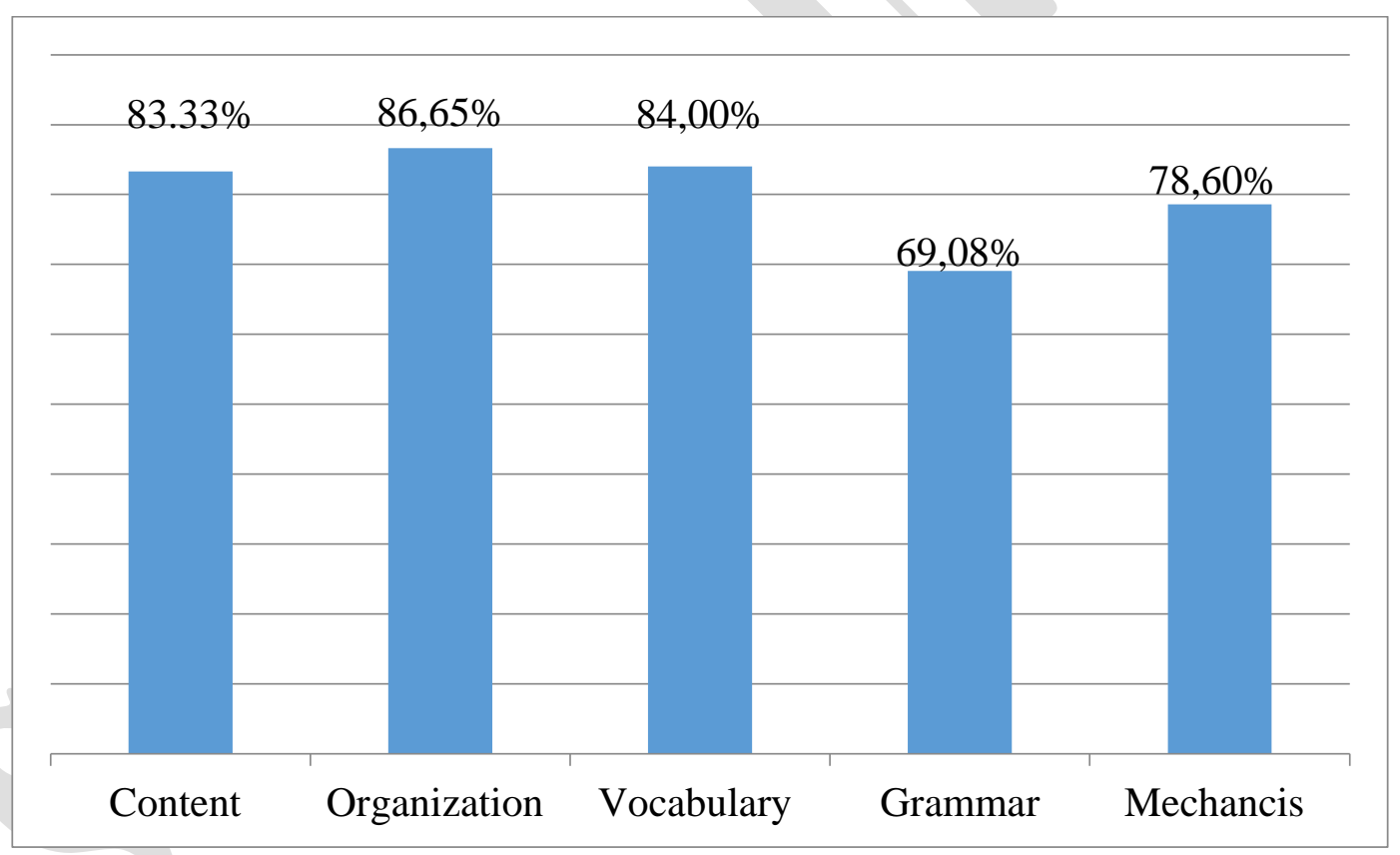

Figure 2 The percentage of the students' narrative paragraph writing ability based on each of writing aspects

From the table 2 and the figure 2, it could be stated that the EFL students' ability in writing the narrative paragraph for each of writing aspects was almost similar about $80 \%$ (content, organization, and vocabulary). It means that these components were excellent categorized. Meanwhile, the aspect of grammar was 69.08 or fair categorized. And the aspect of mechanics was 78.60 or good categorized. 


\section{The Sentence Patterns of Syntax Found on the EFL Students' Narrative Paragraph}

It has been mentioned that the writing test result of the EFL students' narrative paragraph was also used as data source to know the patterns of syntax in which the sentences found on their writing were analyzed using the patterns of syntax presented by Hornby (1976) that focused on the verb patterns. The researcher found 15 from 25 types of the verb patterns as shown below;

\section{Verb Pattern 1: $V b x$ Direct Object}

This pattern found on the students' narrative paragraph writing. The followings were the extracts of sentences made by the students as follows:

- I had prepared my needs such as clothes, foods, drinks, etc.

- The event also held a cake decorating contest and food fairs.

- I couldn't enjoy the view because the place was covered by the fog.

\section{Verb Pattern 2: $\boldsymbol{V b} \boldsymbol{x}$ (not) to $x$ Infinitive}

This pattern was also found on the students' narrative paragraph writing. The examples of finding could be seen below:

- Because, I didn't want to waste my effort teaching them from zero.

- We already promised to meet together at my house just for done our assignment.

- I was so excited to help my parents with my brother.

\section{Verb Pattern 3: $V b x$ Noun or Pronoun $x$ (not) to $x$ Infinitive, etc}

The students also created their sentences of narrative paragraph using this pattern. It refers to the use of verbs may be followed by a noun or pronoun and by (not) to and an infinitive. It can be seen from the followings:

- One day at my grandfather's house, my parents helped uncle to pick vegetables in the field.

I also invited William to catch a fish.

\section{Verb Pattern 5: Vb $x$ Noun or Pronoun $x$ Infinitive, etc}

The researcher also found the sentence type of syntax on the student's narrative paragraph writing using this pattern. The following was the finding as follow:

- She tells me want to school together.

\section{Verb Pattern 6: $\mathrm{Vb} x$ Noun or Pronoun $x$ Present Participle}

In this pattern, the student made the sentence in which the verb was followed by a noun then using present participle. The following was the finding:

Script Journal Volume 1, Issue 1, April 2016 || ISSN 2477-1880 || E-ISSN 2502-6623

http://jurnal.fkip-uwgm.ac.id/index.php/Script 
- And my sister was helping my auntie preparing plates, glasses, and all the stuff required.

\section{Verb Pattern 10: Vb $x$ Object $x$ Adverb or Adverbial Phrase, etc}

The students created their sentences in which the verbs were followed by an object and adverb or an adverbial phrase. The extracts of findings can be seen bellow:

- At the time, my uncle had harvest peppers from morning until noon.

- I wish my basketball students could be always together forever.

- I, my mother and my uncle got part of a job to pick the corn.

\section{Verb Pattern 11: Vb $x$ that-clause}

This pattern categorized the use of verbs may be followed by directly a that-clause (Hornby: 1976). It can be seen from the following extracts:

- I never expected that someone would celebrate it.

- I thought that the one who would give me present would be my childhood.

- I thought that it was very interesting moment, when people looked and gave applause after your performance.

\section{Verb Pattern 15: Vb $x$ Conjunctive $x$ Clause}

In this pattern, the verbs may be followed by a clause introduced by a conjunctive. If is sometimes used instead of whether. This pattern also found on the students' narrative paragraph writing. The followings were the findings:

- And it would be a surprise if they came.

- So he knows how many people were involved.

- That was why I had much brave to join it.

- Although, they were still awkward and shy when they met us.

\section{Verb Pattern 16: $V b x$ Noun or Pronoun $x$ Conjunctive $x$ Clause}

In this pattern, the verbs may be followed by a noun or pronoun and a clause introduced a conjunctive. The finding can be seen from the following extract:

- And it was closed by "Apel Tahunan" which all of the chief of each institutes and all of the teachers came together to the field for annual ceremony.

10. Verb Pattern 17: Vb $x$ Gerund, etc

The finding of this pattern can be seen from the following findings:

- I love playing in the river.

- Her wife named Hwa Yong was killed and found floating on the lake.

- After we finished singing.

Script Journal Volume 1, Issue 1, April 2016 || ISSN 2477-1880 || E-ISSN 2502-6623 http://jurnal.fkip-uwgm.ac.id/index.php/Script 


\section{Verb Pattern 18: Vb $x$ Direct Object $x$ Preposition $x$ Prepositional Object}

In this pattern, the verbs may be followed by a direct object, a preposition, and a prepositional object (which may be a noun, pronoun, gerund, or clause). In this patter has been found. The following was the finding:

- As you could see everybody was busy with their own computer.

\section{Verb Pattern 20: $\mathrm{Vb} x$ (for) Complement of Distance, Time, Price, etc}

It's also found on this type of syntax in which the verbs may be followed by a complement expressing duration, distance, price, or weight. The preposition for is used with some of the verbs in this pattern but is often omitted. Here was the finding:

- We should pay for our journey and stayed for 2 days.

\section{Verb Pattern 21: Vb alone}

The verbs of this pattern may be used without a complement. Such verbs are called complete intransitive verbs. Some verbs which are normally used with an object may also in this pattern, the object being understood. From data analysis, it has been found this pattern of the students' writing that can be seen from the following extracts:

- The last years, one school cheered.

- After new year's day, they swept again.

- That time, the electricity was extinguishing.

\section{Verb Pattern 22: $\mathrm{Vb} \times$ Predicative}

The students made their sentences using this pattern can be seen from the following findings:

I was speechless.

- He was really sad.

- We kept spirit in the bus.

\section{Verb Pattern 24: $V b x$ Preposition $x$ Prepositional Object}

Verbs may be followed by a preposition and a prepositional object (which may be a noun, pronoun, gerund, phrase, or clause). This pattern found on the students' writing. The findings were:

- William and I were playing on the river while looking a small fish.

- We were very excited for our planning to the beach, including me because it was my first time to be the Beras Basah Beach. 
My mom and Rara joined with my dad, my aunt joined with my uncle, Bondan joined with Nanang, and Elvi joined with me.

\section{DISCUSSION}

Based on the data analysis, it showed that the mean score of the EFL students' ability of narrative paragraph was 80.33. It indicated that their ability was categorized excellent. This finding was mostly same with their ability for each of writing aspects such as content, organization, and vocabulary with the average percentage of $80 \%$ above although the language use was $69.08 \%$ and the mechanics was $78.60 \%$. Therefore, the EFL students needed to increase narrative paragraph writing ability especially in terms of language use and mechanics.

Moreover, the sentences made by the EFL students in organizing the narrative paragraph contained some patterns of syntax presented by Hornby (1976). There were 15 of 25 types of verb patterns of their sentences. The verbs were followed by direct object, infinitive, pronoun, present participle, adverbial phrase, that-clause, conjunctive-clause, gerund, direct object-preposition-prepositional object, complement of distance and time, verb alone, predicative and preposition-prepositional object.

Seeing the findings above, it could be said that the EFL students were able to arrange the words, phrases, and clauses to be good sentences and were systematically arrangement. Therefore, their writing ability in this study was categorized excellent. Sotillo (2000) asserted that the syntactic complexity was the ability to produce the writing especially the use of subordinate and embedded subordinate clauses. Moreover, the good sentence arrangement made by the EFL students was relevant with Finch (2000) who stated that the English deals with the words order and combine those words to form sentences. On the contrary, the findings of this study showed different result found by Hijjo (2013) reported that the students could not build a simple sentence due to the different word-order and sentence structure between Malay language and English in term of morphology and syntax. It might be caused by the status of English as a second language in the previous study; since some studies reported that there was any interference between the students' mother tongue/ first language and English during the process of English writing (Alamin \& Ahmed, 2012; Ngangbam, 2016).

Script Journal Volume 1, Issue 1, April 2016 || ISSN 2477-1880 || E-ISSN 2502-6623 


\section{CONCLUSION}

The findings of the current study clearly indicated about the ability of writing paragraph in the second semester EFL students of IAIN Samarinda in the academic year 2015/2016.

The EFL students' ability in writing the narrative paragraph was excellent categorized with 80.33 in the average score. The aspect of organization was the highest ability achieved by the EFL students, followed by vocabulary, content, mechanics, and the least was language use.

The sentence patterns of syntax found on the EFL students' narrative paragraph; its verbs were followed by direct object, infinitive, pronoun, present participle, adverbial phrase, that-clause, conjunctive-clause, gerund, direct object-preposition-prepositional object, complement of distance and time, verb alone, predicative and preposition-prepositional object.

\section{BIBLIOGRAPHY}

Alamin, A., \& Ahmed, S. (2012). Syntactical and punctuation errors: An analysis of technical writing of university students science college. English Language Teaching, 5(5).

Crystal, D. (2003). English as a global language. Cambridge: Cambridge University Press.

Finch, G. (2000). Linguistic terms and concepts. New York: St. Martin's Press.

Gay, L. R., Mills, G. E., \& Airasian, P. . (2012). Educational Research: Competencies for analysis and applications. Boston: Pearson.

Hijjo, N. F. . (2013). A morphosyntactic analysis on Malaysian secondary school students' essay writing in English class. International Journal of Humanities and Social Science, $3(11)$.

Hornby, A. . (1976). Guide to patterns and use in English. Oxford: Oxford University Press.

Ivone, F. M. (2005). Teaching English as a Foreign Language in Indonesia: the Urge to Improve Classroom Vocabulary Instruction. TEFLIN Journal, 16(2).

Jacobs, H. L., Zinkgraf, S. A., Wormuth, D. R., Hartfiel, V. F., \& Hughey, J. B. (1981). English Composition Program: Testing ESL Composition: A practical approach. London: Newbury House Publishers, Inc.

Lauder, A. (2008). The Status and Function of English in Indonesia: A Review of Key Factors. Makara, Social Humaniora Journal, 12(1).

Lie, A. (2007). Education Policy and EFL Curriculum in Indonesia: Between the Commitment to Competence and the Quest for Higher Test Scores. TEFLIN Journal, $18(1)$.

Script Journal Volume 1, Issue 1, April 2016 || ISSN 2477-1880 || E-ISSN 2502-6623

http://jurnal.fkip-uwgm.ac.id/index.php/Script 
Ngangbam, H. (2016). An analysis of syntactic errors committed by students of English Language Class in the written composition of Mutah University: A case study. European Journal of English Language, Linguistics and Literature, 3(1).

Nurhanifah, D., \& Widayati, S. (2005). The Problems of Second Grade Students of SMPN 4 Malang in Learning English and the Efforts Made to Overcome Them. TEFLIN Journal, $16(3)$.

Rao, Z. (2007). Training in brainstorming and developing writing skills. ELT Journal, 61(2).

Rochman, S. (2003). Indonesian Students Misconception in Using Present Perfect Tense to Write Composition. Celt Journal, 3(2).

Sotillo, S. M. (2000). Discourse functions and syntactic complexity in synchronous and asynchronous communication. Language Learning \& Technology, 4(1).

Widiati, U. (2002). Problems with peer response of writing-as-a-process approach in an EFL writing classroom. Jurnal Ilmu Pendidikan, 9(3). 